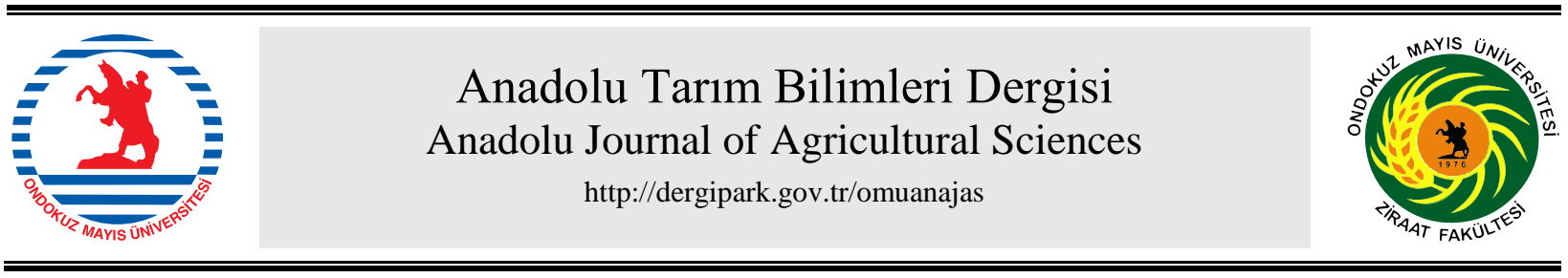

Research/Araştırma

Anadolu Tarım Bilim. Derg./Anadolu J Agr Sci, 32 (2017)

ISSN: 1308-8750 (Print) 1308-8769 (Online)

doi: 10.7161/omuanajas.289586

\title{
Effects of organic conditioner applications on soil loss under simulated rainfall conditioner
}

\author{
Nutullah Özdemir ${ }^{\mathrm{a}}$, Elif Öztürk ${ }^{\mathrm{b}}$, Ömrüm Tebessüm Kop Durmuş ${ }^{\mathrm{a} *}$ \\ ${ }^{a}$ Ondokuz, Mayis University, Faculty of Agriculture, Department of Soil Science and Plant Nutrition, 5200 Atakum, Samsun \\ ${ }^{b}$ Black Sea Agricultural Research Institute \\ *Corresponding author/sorumlu yazar: tebessum.kopdurmus@omu.edu.tr
}

Received/Geliş 27/09/2016 Accepted/Kabul 09/11/2016

\begin{abstract}
This study was conducted to determine effects of farmyard manure, rice husk and municipal waste compost on soil loss caused by runoff in two different soil groups under greenhouse conditions. Soils used in the study were classified as Lithic Ustorthent and Typic Calciustept located in Minöz Basin of Samsun province. Organic conditioners were applied to the soils of basin according to dry weight basis at four different doses $(0,2,4$ and $6 \%)$ under greenhouse conditions. Experiment was planned in a randomized factorial plot design with two replications. After a 12 -week incubation period, $15 \%$ slope was given to erosion pans and $55 \mathrm{~mm} \mathrm{~h}^{-1}$ and $70 \mathrm{~mm} \mathrm{~h}^{-1}$ artificial rainfall intensities were applied for one hour and soil loss values caused by runoff were measured. At the end of the experiment, it was determined that organic conditioners applied to the soils reduced soil losses. Municipal waste compost was determined to be more effective than rice husk compost and farmyard manure in reducing soil losses occurred in runoff pans. Effectiveness of organic conditioners showed differences depend on application doses and the lowest soil loss in each obtained at the maximum dose. The results suggest that using organic conditioners in the agricultural fields reduces soil degradation and loss.
\end{abstract}

Organik düzenleyici uygulamalarının yapay yağış koşulları altında toprak kaybı üzerine etkileri

\section{ÖZET}

Bu çalışma sera koşullarında iki farklı toprak grubunda çeltik kavuzu kompostu, ahır gübresi ve çöp kompostu uygulamalarının yüzey akışla meydana gelen toprak kayıpları üzerine etkilerini belirlemek üzere yürütülmüştür. Bu amaçla çalışmada Samsun ili sınırları içerisinde bulunan Minoz Havzası'nda yayılım gösteren Lithic Ustorthent ve Typic Calciustept olarak sınıflandırılan topraklar kullanılmıştır. Bozulmuş toprak örneklerine ( 8 mm'den küçük agregatlar) organik düzenleyiciler kuru ağırlık esasına göre farklı dozlarda (\% 0, 2, 4 ve 6) uygulanarak simulasyon ünitesi altında ve sera koşullarında uygulamalar yapılmıştır. Denemeler tesadüf parselleri deneme deseninde, faktöriyel düzende ve iki tekrarlamalı olarak yürütülmüştür. 12 haftalık inkübasyon periyodunun ardından erozyon tavalarına \% 15 eğim verilerek $55 \mathrm{~mm} \mathrm{~h}^{-1}$ ve $70 \mathrm{~mm} \mathrm{~h}^{-1}$ intensiteli yapay yağışlar 1 saat süre ile uygulanmış ve yüzey akışla kaybolan toprak miktarı ölçülmüştür. Deneme sonucunda topraklara uygulanan organik düzenleyicilerin toprak kayıplarını azalttığı belirlenmiştir. Erozyon ve yüzey akış miktarlarını azaltmada çöp kompostu, çeltik kavuzu kompostu ve ahır gübresine oranla daha etkili olarak belirlenmiştir. Organik düzenleyicilerin etkinlikleri uygulama dozlarına bağlı olarak farklılıklar göstermiş̧iir ve en düşük kayıplar max doz uygulamalarından elde edilmiştir. Sonuçlara göre, çeltik kavuzu kompostu, çöp kompostu ve organik düzenleyicilerin tarımsal alanlarda toprak bozulmasını ve kaybını azalttı̆̆ı gerekçesiyle kullanımı önerilmektedir.

Keywords:

Erosion

Organic conditioner

Rainfall simulation

\section{Introduction}

Soil is as vital as water and air, and a resource that is benefited from for thousands of years. However rapid increase in world population and the growth of emerging economy has led to greater use of soil. As a result, more intensive use of soil for different purposes 
and its negative impact on the environment brought about some important issues such as erosion. Erosion, defined as degradation and removal of soil from one location, followed by its transport to and deposit at another location one of the main factors restrictsmultifunctional function of soil (Özdemir, 2002). When erosion continued as a natural process and event till people began to the activities on the earth, it lost property of natural process after people started to use of nature and soils and has gained a different dimension (Çepel et al., 2006). Erosion is seen as a major problem all over the world and it requires conservation measures to counteract its negative impact on soil productivity (Tunç and Schröder, 2010).

Despite erosion studies in natural conditions give the most accurate results, conducting these studies in very large areas is difficult and very expensive. Obtaining results may take as long as 15-20 years. Therefore, researchers prefer to conduct erosion studies based on rainfall simulators and laboratory experiments to obtain results in shorter time (Young and Burwell, 1972; Meyer and Harmon, 1979; Taysun, 1981). Thus, various soil samples taken from wide agricultural areas are subjected to erosion tests with rainfall simulators in laboratory conditions and this can provide an idea about susceptibility to degradation in a short time.

One of the most effective measures to be taken in order to improve degraded physical, chemical and biological properties of soils, ensure the continuity of productivity, protect them from negative effects of destructive processes such as erosion is associated with supplying organic matter in the soil above a certain level, constantly. Evaluation of organic wastes as a conditioner is very important in terms of reducing erosion, improving water quality, continuity of healthy products in sustainability of soil quality. Organic matter is effective on many soil properties and processes occurring in soil (Doran and Parkin, 1994; Gregorich et al., 1994; Lal and Kimble, 1997). Especially having an adequate level of organic matter in surface soil improves the soil quality and its physical, chemical and biological properties (Sojka and Upchurch, 1999).

This study aims to evaluate the effects of organic waste conditioners on soil property degradation and soil loss caused under different simulated rainfall intensities. Specifically, farmyard manure, rice husk and municipal waste composts are considered as soil conditioners. Two different soil groups located in Minöz Basin of Samsun province and different rainfall intensities are investigated with rainfall simulator.

\section{Material and Methods}

\subsection{Material}

This study was conducted by using degraded surface soil samples classified as Lithic Ustorthent and Typic Calciustept taken from Minöz Basin located within the boundaries of Samsun province. This study was conducted by using degraded surface soil samples classified as Lithic Ustorthent and Typic Calciustept taken from Minöz Basin located within the boundaries of Samsun province. The soils were classified according to the criteria proposed by the Soil Taxonomy (1999) based on their morphological, physical and chemical characteristics. Physical and chemical analysis results of surface soil samples were taken from Yakupoğlu (2010) and given in Table 1 and Table 2. Water passed through a purification unit was used to create simulated rainfall in the study. Some anion and cation contents and chemical properties of this water were given in Table 3 (Yakupoğlu, 2010). Farmyard manure, rice husk and municipal waste compost were the organic conditioners used in this study. Analysis results of these conditioners are given in Table 4.

Table 1. Chemical analysis results of experiment soils

\begin{tabular}{|c|c|c|c|c|c|c|c|c|c|c|}
\hline \multirow{2}{*}{ Soils } & \multirow{2}{*}{$\mathrm{pH}$} & \multirow{2}{*}{$\begin{array}{c}\mathrm{EC} \\
\mathrm{dS} \mathrm{\textrm {m } ^ { - 1 }}\end{array}$} & \multirow{2}{*}{$\begin{array}{c}\text { Total } \\
\text { Salt } \\
\%\end{array}$} & \multirow{2}{*}{$\begin{array}{c}\mathrm{CaCO}_{3} \\
\%\end{array}$} & \multirow{2}{*}{$\begin{array}{c}\mathrm{OM} \\
\%\end{array}$} & \multirow{2}{*}{$\begin{array}{c}\text { CEC } \\
\mathrm{cmol} \mathrm{kg}^{-1}\end{array}$} & \multicolumn{4}{|c|}{$\begin{array}{l}\text { Exchangeable cations } \\
\text { cmokg }^{-1}\end{array}$} \\
\hline & & & & & & & $\mathrm{Na}^{+}$ & $\mathrm{K}^{+}$ & $\mathrm{Ca}^{2+}$ & $\mathrm{Mg}^{2+}$ \\
\hline $\begin{array}{l}\text { Lithic } \\
\text { Ustorthent } \\
\text { Typic }\end{array}$ & 7.18 & 0.221 & 0.006 & 3.98 & 1.68 & 7.39 & 0.59 & 0.21 & 5.12 & 1.83 \\
\hline Calciustept & 7.08 & 0.439 & 0.013 & 0.81 & 1.97 & 33.29 & 0.19 & 0.42 & 20.24 & 12.34 \\
\hline
\end{tabular}

Table 2. Physical analysis results of experiment soils

\begin{tabular}{|c|c|c|c|c|c|c|c|c|c|}
\hline \multirow[b]{2}{*}{ Soils } & \multicolumn{4}{|c|}{ Texture } & \multirow{2}{*}{$\begin{array}{l}\text { Color (Dry, } \\
\text { Wet) }\end{array}$} & \multirow{2}{*}{$\begin{array}{l}\text { Hyd. } \\
\text { cond. } \\
\mathrm{cm} \mathrm{h}^{-1}\end{array}$} & \multirow{2}{*}{$\begin{array}{c}\mathrm{FC} \\
\%\end{array}$} & \multirow{2}{*}{$\begin{array}{l}\text { WP } \\
\%\end{array}$} & \multirow{2}{*}{$\begin{array}{c}\text { Available } \\
\text { water } \\
\%\end{array}$} \\
\hline & $\begin{array}{c}\text { Sand } \\
\%\end{array}$ & $\begin{array}{l}\text { Silt } \\
\%\end{array}$ & $\begin{array}{c}\text { Clay } \\
\%\end{array}$ & Class & & & & & \\
\hline Lithic & & & & & 2.5 & & & & \\
\hline $\begin{array}{l}\text { Ustorthent } \\
\text { Typic }\end{array}$ & 67.68 & 22.46 & 9.86 & SL & $\begin{array}{l}2.5 Y 4 / 3 \\
2.5 Y 5 / 3\end{array}$ & 56.57 & 16.1 & 7.4 & 8.7 \\
\hline Calciustept & 34.6 & 33.9 & 31.5 & $\mathrm{CL}$ & $2.5 \mathrm{Y} 4 / 4$ & 9.56 & 33.6 & 20.1 & 13.5 \\
\hline
\end{tabular}


Table 3. Some chemical properties of simulated rainfall water

\begin{tabular}{|c|c|c|c|c|c|c|c|c|c|c|c|}
\hline \multicolumn{4}{|c|}{ Cations (me L $\mathrm{L}^{-1}$ ) } & \multicolumn{4}{|c|}{ Anions (me $\mathrm{L}^{-1}$ ) } & \multirow[b]{2}{*}{$\mathrm{pH}$} & \multirow{2}{*}{$\begin{array}{c}\mathrm{EC} \\
\mathrm{dS} \mathrm{m}^{-1} \\
\end{array}$} & \multirow{2}{*}{$\begin{array}{c}\mathrm{B} \\
\mathrm{mg} \mathrm{L}^{-1} \\
\end{array}$} & \multirow[b]{2}{*}{ SAR } \\
\hline $\mathrm{Na}^{+}$ & $\mathrm{K}^{+}$ & $\mathrm{Ca}^{2+}$ & $\mathrm{Mg}^{2+}$ & $\mathrm{CO}_{3}{ }^{2-}$ & $\mathrm{HCO}_{3}^{-}$ & $\mathrm{Cl}^{-}$ & $\mathrm{SO}_{4}{ }^{2-}$ & & & & \\
\hline 0.7 & 0.1 & 0.95 & 1.90 & 0.2 & 1.25 & 0.8 & 1.35 & 7.41 & 0.336 & 0 & 0.42 \\
\hline
\end{tabular}

Table 4. Contents of organic conditioners used in the study

\begin{tabular}{cccc}
\hline \multirow{2}{*}{ Analysis } & \multicolumn{3}{c}{ Organic conditioners } \\
\cline { 2 - 4 } $\mathrm{pH}$ & Farmyard manure & Municipal waste compost & Rice husk compost \\
\hline $\mathrm{EC}, \mathrm{dS} \mathrm{m}{ }^{-1}$ & 7.48 & 8.07 & 7.81 \\
$\mathrm{OM}, \%$ & 4.29 & 3.10 & 0.51 \\
$\mathrm{OC}, \%$ & 28.32 & 35.71 & 19.82 \\
$\mathrm{~N}, \%$ & 14.16 & 17.86 & 9.91 \\
$\mathrm{C} / \mathrm{N}$ & 1.74 & 1.55 & 0.88 \\
$\mathrm{P}, \%$ & 8.14 & 11.52 & 11.26 \\
$\mathrm{~K}, \%$ & 1.706 & 0.202 & 0.357 \\
$\mathrm{Na}, \%$ & 0.130 & 0.638 & 0.401 \\
$\mathrm{Ca}, \%$ & 0.432 & 0.115 \\
$\mathrm{Mg}, \%$ & 0.290 & 9.919 & 0.460 \\
$\mathrm{Fe}, \%$ & 2.959 & 0.345 & 0.364 \\
$\mathrm{Cu}, \%$ & 0.588 & 0.467 & 1.060 \\
$\mathrm{Zn}, \%$ & 0.230 & 0.012 & 0.001 \\
$\mathrm{Mn}, \%$ & 0.003 & 0.025 & 0.008 \\
\hline
\end{tabular}

EC: Electirical conductivity; OM: Organic matter; OC: Organic carbon

\subsection{Method}

\subsubsection{The establishment and execution of greenhouse experiment}

Degraded soil samples of the basin were dried indoors and then passed through a sieve with diameter of $8 \mathrm{~mm}$. Before the experiment, all organic conditioners were passed through a sieve with a diameter of $4.75 \mathrm{~mm}$ in order to have a uniform particle size distribution. The erosion pans used in this surface flow study had the dimensions $30 \times 29.5 \times 15 \mathrm{~cm}$ (lengthwidth-depth), and had drainage outlets. The bases of the pans were covered with paper filters (Karaoğlu ve Çanga, 2002) and filled with $10 \mathrm{~cm}$ thick sea-sand. Surface of sea sand was leveled carefully and then cheesecloth was laid on the sand. The remaining $5 \mathrm{~cm}$ of the pans were filled with the mixture of soil+organic conditioners. Organic conditioners were applied to the soils in order to increase organic matter contents of soils up to the $0,2,4$ and $6 \%$, according to dry weight basis. Experiment was planned in a randomized factorial plot design with two replications. After the addition of organic conditioners, pans were incubated for 12 weeks under greenhouse conditions. Water was added by measuring weights of pans until the moisture contentreached up to the field capacity, during this period. After the 12-weeks incubation period, artificial rainfall with $55 \mathrm{~mm} \mathrm{~h}-1$ and $70 \mathrm{~mm} \mathrm{~h}-1$ intensities were applied to the pans by the simulator and soil losses caused by runoff were determined at $15 \%$ slope. This slope was preferred because of it being the limit value in terms of soil cultivation (Özdemir, 2002)

\subsubsection{The methods used to determine rainfall characteristics and soil losses}

A laboratory type simulator modified from Erpul and Çanga (2001) was used to create simulated rainfalls in the study (Figure 1).

Christiansen uniformity coeffient $(\mathrm{Cv})$, rainfall intensity $\left(\mathrm{I}, \mathrm{mm} \mathrm{h}^{-1}\right)$ and kinetic energy (KE, $\left.\mathrm{J} \mathrm{m}^{-2}-\mathrm{mm}\right)$ were taken into account to define these simulated rainfall characteristics. $\mathrm{Cv}$ values in the rainfall basin were determined by Equation 2.1 (Erpul and Çanga, 2001). Intensities of rainfall were measured with Vantage PRO2 type air station kit. Kinetic energy values of rainfalls were determined by Equation 2.2 (Hudson, 1995). 


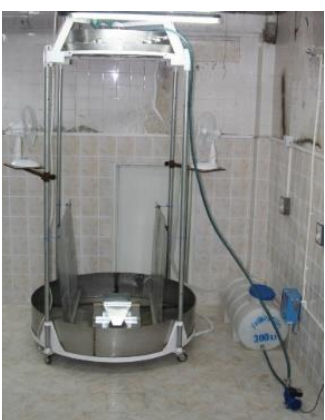

Figure 1. General view of rainfall simulator

$C v=1-s /$ Iort

Where; $\mathrm{s}=$ standard deviation, $\left(\mathrm{mm} \mathrm{h}^{-1}\right)$

$$
K E=11.9+8.7 \log I
$$

Characteristics of simulated rainfall were determined by using the said kit and equations as follows: rainfall intensities of $55 \mathrm{~mm} \mathrm{~h}^{-1}$ and $70 \mathrm{~mm} \mathrm{~h}^{-1}, \mathrm{Cv}$ values of 0.82 and 0.86 and kinetic energy values of $27.04 \mathrm{~J} \mathrm{~m}^{-2}$ $\mathrm{mm}$ and $27.95 \mathrm{~J} \mathrm{~m}^{-2}-\mathrm{mm}$. Two fans were incorporated into the system to form wind effects seen in natural conditions. This ensured that the rain drops were falling onto the soil surface at a certain angle. Samples were taken into the containers placed under the discharge opening of the pans with the start of runoff for 1 hour. Soils in the containers were dried in the oven at $105^{\circ} \mathrm{C}$ and weighed to calculate amount of soil lost by runoff (Yönter and Geren, 2006). Soil loss occured from the pans of each application was expressed by calculation as $\mathrm{kg} \mathrm{da}^{-1}$, at the end of the experiment. TARIST (1994) software was used for statistical analysis.

\section{Results and Discussion}

Simulated rainfalls with two different intensities were applied to the erosion pans in the laboratory and the amounts of soil loss occurred by runoff were determined after the incubation experiment conducted under greenhouse conditions. Amounts of soil losses observed by this way in both soil groups are given in Table 5. The maximum loss in Lithic Ustorthent soil during the rainfall with the intensity of $55 \mathrm{~mm} \mathrm{~h}^{-1}$ was observed as $953 \mathrm{~kg} \mathrm{da}^{-1}$ in the control treatment and the minimum loss was observed as $241 \mathrm{~kg} \mathrm{da}^{-1}$ in $6 \%$ dose application of rice husk compost. In the maximum dose applications of rice husk compost (RHC), municipal waste compost (MWC) and farmyard manure (FM) under this rainfall, a decreases in soil loss of $712 \mathrm{~kg} \mathrm{da}^{-}$ 1, $658 \mathrm{~kg} \mathrm{da}^{-1}$ and $587 \mathrm{~kg} \mathrm{da}^{-1}$ occurred compared to the control treatment, respectively. The maximum soil loss was determined as $1304 \mathrm{~kg} \mathrm{da}^{-1}$ in the control treatment in this soil group during the rainfall with the intensity of
$70 \mathrm{~mm} \mathrm{~h}^{-1}$. The minimum soil loss was observed as being $902 \mathrm{~kg} \mathrm{da}^{-1}$ in the $6 \%$ dose application of RHC. Soil losses by runoff varied depending on organic conditioners types and decreased with increasing application dose. Losses were observed as $1231 \mathrm{~kg} \mathrm{da}^{-1}$ for RHC, $1139 \mathrm{~kg} \mathrm{da}^{-1}$ for MWC and $1254 \mathrm{~kg} \mathrm{da}^{-1}$ for $\mathrm{FM}$, in the minimum dose applications. In the maximum dose applications, a decreases in soil loss of $402 \mathrm{~kg} \mathrm{da}^{-1}$ (RHC), $366 \mathrm{~kg} \mathrm{da}^{-1}$ (MWC) and $141 \mathrm{~kg} \mathrm{da}^{-1}$ (FM) were observed compared to the control treatment. Generally, $4 \%$ dose of applications was between maximum and minimum doses in terms of efficiency. The maximum soil loss was observed as $1663 \mathrm{~kg} \mathrm{da}^{-1}$ in the control treatment and the minimum soil loss was observed as $699 \mathrm{~kg} \mathrm{da}^{-1}$ in the $6 \%$ dose of MWC application in Typic Calciustept soil group during the rainfall with the intensity of $55 \mathrm{~mm} \mathrm{~h}^{-1}$ (Table 5). Soil losses occurred in the maximum dose applications of conditioners determined as $821 \mathrm{~kg} \mathrm{da}^{-1}, 699 \mathrm{~kg} \mathrm{da}^{-1}$ and $950 \mathrm{~kg} \mathrm{da}^{-1}$ for RHC, MWC and FM, respectively. Soil losses in minimum conditioner applications were defined as 1236 $\mathrm{kg} \mathrm{da}^{-1}$ (RHC), $1299 \mathrm{~kg} \mathrm{da}^{-1}$ (FM) and $1096 \mathrm{~kg} \mathrm{da}^{-1}$ (MWC). In this soil group, the maximum loss occurred in the control treatment as $3559 \mathrm{~kg} \mathrm{da}^{-1}$ during the rainfall with the intensity of $70 \mathrm{~mm} \mathrm{~h}^{-1}$. The minimum loss in this intensity was determined in the $6 \%$ dose of MWC as $2185 \mathrm{~kg} \mathrm{da}^{-1}$. Soil losses were observed as $3215 \mathrm{~kg} \mathrm{da}^{-1}$ for RHC, $2650 \mathrm{~kg} \mathrm{da}^{-1}$ for MWC and 3063 $\mathrm{kg} \mathrm{da}^{-1}$ for $\mathrm{FM}$ in the minimum dose applications of conditioners. In $4 \%$ dose applications, losses were determined as $2832 \mathrm{~kg} \mathrm{da}^{-1}, 2804 \mathrm{~kg} \mathrm{da}^{-1}$ and $2337 \mathrm{~kg}$ $\mathrm{da}^{-1}$ for RHC, FM and MWC, respectively. Variance analysis was used to assess the effects of the organic conditioner application and the on soil losses caused by runoff in the simulation experiment planned in a randomized plot design as a factorial arrangement. Effects of organic conditioner type and dose, soil type and rainfall intensity on this parameter were found significant $(P<0.001) . \quad$ LSD $_{0.05}$ test was used in the comparison of average variable measurement valuables of applications after determination of significance of issues and interactions between these issues. Results of $\mathrm{LSD}_{0.05}$ test for variable of soil losses caused by runoff determined in two different soil groups in the simulation application performed for 1 hour under two different rainfall intensities are given Table 6 . As seen in the table, soil losses showed differences for both rainfall intensities statistically and the maximum losses occurred in Typic Calciustept. Comparison of the efficiency of organic conditioners used in the experiment on the losses caused by runoff in each soil is given in Table 7. Effects of the organic conditioners on the variables were statistically different. Municipal waste compost was determined as the most effective application in terms of reducing the soil loss in both soil types when the efficiency of organic conditioners was evaluated. Rice husk compost was the second best and farm yard manure was determined as the least effective as it showed the least reduction in soil loss. 
Table 5.Soil losses occurred by runoff in Lithic Ustorthent and Typic Calciustept

\begin{tabular}{|c|c|c|c|}
\hline \multirow{2}{*}{$\begin{array}{l}\text { Rainfall intensity } \\
\mathrm{mm} \mathrm{h}^{-1}\end{array}$} & \multirow{2}{*}{ Application } & \multicolumn{2}{|c|}{ Soil losses, $\mathrm{kg} \mathrm{da}^{-1}$} \\
\hline & & Lithic Ustorthent & Typic Calciustept \\
\hline \multirow{10}{*}{55} & Control & 953 & 1663 \\
\hline & RHC-2 & 654 & 1236 \\
\hline & RHC-4 & 261 & 893 \\
\hline & RHC-6 & 241 & 821 \\
\hline & MWC-2 & 449 & 1096 \\
\hline & MWC-4 & 394 & 979 \\
\hline & MWC-6 & 295 & 699 \\
\hline & FM-2 & 495 & 1299 \\
\hline & FM-4 & 493 & 1205 \\
\hline & FM-6 & 366 & 950 \\
\hline \multirow{10}{*}{70} & Control & 1304 & 3559 \\
\hline & RHC-2 & 1231 & 3215 \\
\hline & RHC-4 & 1111 & 2832 \\
\hline & RHC-6 & 902 & 2208 \\
\hline & MWC-2 & 1139 & 2650 \\
\hline & MWC-4 & 1045 & 2337 \\
\hline & MWC-6 & 938 & 2185 \\
\hline & FM-2 & 1254 & 3063 \\
\hline & FM-4 & 1204 & 2804 \\
\hline & FM-6 & 1163 & 2533 \\
\hline
\end{tabular}

Table 6. Comprasion of soil losses caused by runoff in two different soils under rainfall intensity with LSD $_{0.05}$

\begin{tabular}{lll}
\hline $\begin{array}{l}\text { Rainfall } \\
\text { intensity }\end{array}$ & Soil & $\begin{array}{l}\text { Soil loss } \\
\mathrm{kg} \mathrm{da}^{-1}\end{array}$ \\
\hline $55 \mathrm{~mm} \mathrm{~h}^{-1}$ & Lithic Ustorthent & $542.250^{\mathrm{b}}$ \\
& Typic Calciustept & $1180.583^{\mathrm{a}}$ \\
\hline $70 \mathrm{~mm} \mathrm{~h}^{-1}$ & Lithic Ustorthent & $1158.250^{\mathrm{b}}$ \\
& Typic Calciustept & $2875.333^{\mathrm{a}}$ \\
\hline
\end{tabular}

When the results of the research examined, differences were determined between two soil groups in terms of the total losses caused by runoff under both rainfall intensities at the end of the simulation period (Table 5). Soils ranged as Typic Calciustept > Lithic Ustorthent in terms of the soil loss. One of the factors effective in this arrangement is probably the common effects of the specific physical and chemical properties of each soil. The difference in soil properties leads to different sensitivity to forces generated by various erosion vausing factors.

Even if all the factors are the same, reactions of the soils to erosion is very different depending on their characteristics and one of them can suffer from the erosion 30 times more than other (Lal, 1990).

When all soil losses under the rainfalls are compared, it is seen that the maximum losses were observed under the higher rainfall intensity of 70 $\mathrm{mm} \mathrm{h}^{-1}$, in both soil groups. Intensity is one of the most important physical rainfall properties that effects erosion. It is generally thought that there is a close relatinship between rainfall intensity and erosion. The consensus is that more rainfall leads to more erosion. When the rainfall intensity increases, its kinetic energy and accordingly the forces of that lead to erosion increase (Özdemir, 2002).

Table 7. Comprasion of soil losses occurred by runoff in two different soils under organic conditioner type with $\mathrm{LSD}_{0.05}$

\begin{tabular}{lll}
\hline Soil & Conditioner & $\begin{array}{l}\text { Soil loss } \\
\mathrm{kg} \mathrm{da}^{-1}\end{array}$ \\
\hline Lithic & RHC & $832.125^{\mathrm{b}}$ \\
Ustorthent & MWC & $814.625^{\mathrm{c}}$ \\
& FM & $904.000^{\mathrm{a}}$ \\
\hline Typic & RHC & $2053.375^{\mathrm{b}}$ \\
Calciustept & MWC & $1896.000^{\mathrm{c}}$ \\
& FM & $2134.500^{\mathrm{a}}$ \\
\hline
\end{tabular}

$\mathrm{LSD}_{0.05}=16.756$

Simulation was carried out by giving $15 \%$ slope to the erosion pans added organic matter in the experiment. When classified, the area represented by the study is expressed as more slopped because of the owned slope level. Therefore, effect of degree of the slope is present on the large amounts of soil losses occurred. Amorim et al. (2001) stated that, soil losses 
increased with increasing slope and kinetic energy, in a study conducted with simulator. When the total losses are examined (Table 5), it was determined that the obtained data showed differences depending on the applied conditioner type and doses. Many studies regarding the application of organic conditioners show a significant decrease in soil loss and an improvement in degraded physiochemical soil properties. When the effectiveness of the conditioner application doses are evaluated, the maximum losses are observed in the control treatments that do not contain any conditioners. The decrease in soil loss were parallel to the increase in dose. The highest dose of $6 \%$ was determined as the most effective application in terms of soil losses. These positive effects of doses are derived from the organic matter content. Increases occurred in the organic matter content generally led to diminishing soil loss in the experiment.

Contents of farmyard manure, rice husk and municipal waste compost were effective in the positive effects of organic conditioners on the losses. When the contents of these conditioners shown in Table 4 are examined, it is seen that municipal waste compost has the highest organic matter content at $35.71 \%$. Farmyard manure and rice husk compost contain $28.32 \%$ and $19.82 \%$ organic matter, respectively. Organic matter prevents erosion by affecting soil aggregation, aeration, water holding capacity and permeability positively (Schnitzer, 1978). Organic matter reduces the susceptibility to the erosion by improving soil's physical, chemical and biological properties (Ö̈zdemir, 2002). Decreases in the losses with the organic conditioners can be attributed to the positive effects of organic matter at the end of the experiment.

\section{Conclusions}

Positive effects of organic conditioners in reducing soil loss were observed in both soil groups with this study. Applications of organic materials and organic wastes to the susceptible soils in reducing soil losses caused by erosion can be an effective method. Usage of municipal waste compost, rice husk compost and similar organic conditioners in this study in the agricultural areas reduce both the losses originated from degradation and the negative effects in terms of human health and environmental pollution. This is a significant contribution to the economy of the country. Organic materials are added to the soils in order to increase the amount of water stable aggregates. In this way with being aggregates in the soil stable it is possible to prevent both soil loss and soil pollution occured as a result of intensive use of chemical inputs. While we apply organic waste in order to reduce erosion related soil losses in our country, we must also prevent losses caused by soil misuse and protect this asset that has such a great importance at every stage of our lives.

\section{References}

Amorim, R.S.S., Silva, D.D., Pruski, F.F., Matos, A.T., 2001. Influence of the soil slope and kinetic energy of simulated precipitation in the interrill erosion process, International Symposium of Soil Erosion Research for the 21 st Century, Honolulu-Hawaii, USA, 3-5 January, Eds: J.C. Ascough, D.C. Flanagan, pp:155-158..

Çepel, N., Yüksel, M., Işık, K., Altın, M., Orak, A., Neyişçi, T., Sarı, M., Ergün, C., 2006. Erozyon, doğa ve çevre, I. Basım, Tema Vakfi Yayını, İstanbul.

Doran, J.W., Parkin, T.B., 1994. Defining and Assessing Soil Quality, Editors: Doran, J.W., Coleman, D.C., Bezdicek, D.F., Stewart, B.A., Defining soil quality for a sustainable environment, SSSA Special Publication No: 35, Madison, 3-21.

Eaton, D.A., Cleascerri, L.S., Greenberg, A.E., 1995. Standard Methods for The Examination of Water and Wastewater, 20th ed., APHA, Washington DC.

Erpul, G., Çanga, M.R., 2001. Toprak erozyon çalışmaları için bir yapay yağmurlama aletinin tasarım prensipleri ve yapay yağış karakteristikleri, Tarım Bilimleri Dergisi, 7(1): 75-83.

Gregorich, E.G., Carter, M.R., Angers, D.A., Monreal, C.M., Ellert B.H., 1994. Towards a minimum data set to assess soil organic matter quality in agricultural soils, Canadian Journal of Soil Science, 74: 367-385.

Hudson N., 1995. Soil Conservation, B.T. Batsford Limited, London, UK.

Karaoğlu, M., Çanga, M.R., 2002. The consecutive simulated rainfall, slope and phosphogypsum's effects on runoff and erosion, International Conference on Sustainable Land Use Management, Sharing Experiences for Sustainable Use of Natural Sources., Proceeding Book, 282-289. 10-13 June Çanakkale, Turkey.

Lal, R., 1990. Soil properties and erodibility, Editor: Lal, R., Soil erosion in the Tropics; principles and management, McGraw-Hill, NewYork, 60-99.

Lal, R., Kimble J.M., 1997. Conservation tillage for carbon sequestration, Nutrient Cycling in Agroecosystems, 49: 243-253.

Meyer, L.D., Harmon, W.C., 1979. Multiple intensity rainfall simulator for erosion research on row sideslopes, ASAABE, 22(1): 100-103.

Özdemir, N., 2002. Toprak ve Su Koruma, OMÜ Ziraat Fakültesi Yayınları, No: 22, 2. Bask1, Samsun.

Schnitzer, M., 1978. Soil Organic Matter, Ed.: M. Schnitzer, S.U. Khan. ESPC, New York.

Soil Taxonomy, 1999. A Basic of Soil Classification for Making and Interpreting Soil Survey, 2nd ed., USDA Handbook No: 436, Washington D.C.

Sojka, R.E., Upchurch, D.R., 1999. Reservations regarding the soil quality concept, SSSAJ, 63: 1039-1054.

TARİST, 1994. İstatistik Program. EÜ Tarım ve Ormancılık Araştırma Enstitüsü Yayınları, İzmir.

Taysun, A., 1981. Gediz Havzası'nın rendzina tarım topraklarında yapay yağmurlayıcı yardımıyla taşlar, bitki artıkları ve polyvinilalkolün (PVA) toprak özellikleri ile birlikte erozyona etkileri üzerinde araştırmalar, Doçentlik Tezi, EÜ Ziraat Fakültesi Toprak Bölümü, Bornova (Yayınlanmamış).

Tunç, E., Schröder, D., 2010. Ankara'nın batısındaki tarım topraklarında USLE ile erozyon boyutunun tespiti, Ekoloji, 19(75): 58-63. 
Yakupoğlu, T., 2010. Samsun İli Minoz ve Gölet Havzalarında Yaygınlık Gösteren Toprakların $\mathrm{Su}$ Erozyonuna Duyarlılıklarının Laboratuar Koşullarında Belirlenmesi. Doktora Tezi. OMÜ Fen Bilimleri Enstitüsü, 126 s, Samsun.

Young, R.A., Burwell, R.E., 1972. Prediction of runoff and erosion from natural rainfall using a rainfall simulator, SSSAJ, 36: 827-830.
Yönter, G., Geren, H., 2006. Farklı mera karışımlarının laboratuar koşullarında su erozyonuna etkisi üzerinde ön araştırmalar, EÜ Ziraat Fakültesi Dergisi, 43(1): 121-131. 